\section{VERSITA}

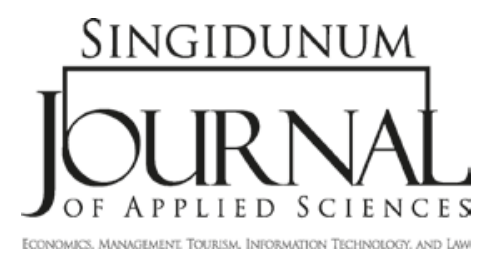

SINGIDUNUM JOURNAL 2013, 10 (2): 19-23

ISSN 2217-8090

UDK 343.24(497.7) ; 364-781.9:343.22(497.7)

DOI 10.5937/sjas10-4714

Original paper/Originalni naučni rad

\title{
PROBATION SERVICE AS PART OF PENITENTIARY SYSTEM IN THE REPUBLIC OF MACEDONIA
}

\author{
Svetlana Veljanovska ${ }^{1, *}$ \\ ${ }^{1}$ University St. Kliment Ohridski - Bitola, Faculty of Law \\ Rudnička Street, Kičevo, Republic of Macedonia
}

\begin{abstract}
:
The reform of the system of execution of sanctions is anticipated in the part of the reform of the criminal justice system of the Republic of Macedonia. The functional system for implementing sanctions in modern criminal justice systems implies a complex approach in which besides the dimension of punishment, the dimensions of social reintegration and victim protection play an important role. In such a context, the so-called probation system, has been established. Event though such system has not been established in the Republic of Macedonia up to now, its elements are contained in the existing legal framework in the material and procedural provisions. Some solutions of the previous system can be used with the aim to establish continuity on institutional and operational level.The starting point for the establishment of probation begins with amendments to the Criminal Code of 2004, where in the part that refers to criminal sanctions, the following alternative measures were imposed: probation, suspended sentence with supervision, conditional discontinuation of criminal proceedings, community service, court sanctions and house arrest.

The probation is primarily directed towards designing and developing the system of regular individualized assessment of perpetrators, assessing the risk of re-offending, identifying objective and subjective reasons for previous criminal activity and enabling people who already served their prison sentence to have an active and meaningful involvement in the community.
\end{abstract}

\section{INTRODUCTION}

The foundation for developing probation in Macedonian society can be related to the development of penitentiary system in former Yugoslavia. The criminal law from 1951 and its changes and amendments foresaw probation with protective monitoring and special obligations for persons who had been sentenced in such manner. Similar measures were foreseen in the Criminal law from 1977 in order to meet the purpose of punishment, i.e. warning through the threat of punishment. This is the foundation framework of the new probation system, which is to provide regulation of probation monitoring. Ac- cording to the definition that views probation as dependent and controlled freedom of the perpetrator the purpose of which is to reduce the risk of crime repetition, it is necessary to highlight that there is no probation system in the Republic of Macedonia. Therefore, the purpose of this paper is to indicate the advantages of probation and its establishment as a sustainable service, which will deal with perpetrators throughout all the phases of the proceedings. Probation service should not only incorporate special features of the Macedonian penitentiary system, but also develop itself in accordance with the rules and standards of the UN, the Council of Europe and the European Union.

^E-mail: svetlanaveljanoska@hotmail.com 
CONDITIONS IN THE REPUBLIC OF MACEDONIA IN THE SPHERE OF CRIME

The survey carried out by the Center for Human Rights and Conflict Resolution puts emphasis on treatment conditions, sanctions and the position of perpetrators in the Republic of Macedonia during the period 2006 - 2010. The basic index has been determined according to data on adults sentenced during the period 1999 - 2010. Based on that, one can infer that the crime rate in Macedonia rose by more than a third during those ten years, which was not the case in any other previous period. The most prevalent types of sentenced crimes include the group of property crime and the group of traffic crimes. Imprisonment is the most common type of sentence, whereas in the segment of alternative measures, probation dominates in $90 \%$, with fines just under $9 \%$. The most common are six-month imprisonments ranging between $38.4 \%$ and $43.5 \%$, followed by six-to-one year imprisonment, which means that two thirds of sentence punishments are short-term ones going up to twelve months).

The analysis of experts' attitudes leads to the conclusion that the most efficient way of preventing crime is through sanctions in the form of imprisonment. However, more than $87 \%$ of the judges and public attorneys maintain that the alternative punishments should be given. As many as $92.2 \%$ of judges and $82.7 \%$ of public attorneys claim that the most common punishment they impose is probation. The reason why they rarely decide for alternative measures and sanctions is due to insufficient conditions and methodology for such sanctions to be taken. Another issue refers to the lack of the system for implementation of alternative sanctions. Namely, $54.4 \%$ of judges and $50.9 \%$ of public attorneys consider themselves representatives for the establishment of the probation system in the country. What is extremely surprising is that a high percentage of survey participants have no opinion concerning this issue (around $32.9 \%$ of judges and 27.3\% of public attorneys), according to the strategy for probation in the Republic of Macedonia.

\section{THE STATUS AND ROLE OF PROBATION SERVICE}

Probation services primarily ought to create conditions for establishing and functioning of the system through creating the appropriate legal and structural framework. A very important condition is to provide human and material resources that could fulfill the tasks set.

From the strategic point of view, probation service should contribute to the overall reform of the penitentiary system. It ought to be operated by social regulatory mechanisms by means of establishing the framework of an efficient system of sanctions and protective mechanisms. Such system should above all be accepted within the community, and provide long-term benefits concerning crime conditions, human protection, indemnification and re-socialization of victims and re-integration of perpetrators through respecting human rights and liberties of all participants involved. These strategic goals are also compatible with the EU processes related to probation.

The range of areas that need to be worked on and that should yield results can generally be divided into five strategic points:

1. Normative and legal framework;

2. Institutional and organizational framework;

3. Work with perpetrators and victims;

4. Providing professional and trained staff;

5. Cooperation and partnership with other institutions.

The area of normative and legal framework includes passing laws and acts as well as the changes of the existing laws in order for probation system to function. The Republic of Macedonia is currently quite reserved concerning this segment and it would be best to begin with the draft law on probation, which could lead to the law with acts that would operate within the probation system.

The institutional and organizational framework includes establishing institutions and organizations that could enable the functioning of the probation system. Part of those would be incorporated within the existing penitentiary system, whereas a certain number of institutions would have to be subsequently established.

Creating and developing the program for perpetrators, collecting data, conducting analysis, making an instrument for determining risk, establishing a notification system, designing a program for dealing with victims is just part of the separate strategic aim, which has been called dealing with perpetrators and victims. In order for all this to be achieved, it is necessary to have professional and trained staff that possesses knowledge and skills necessary for collecting data, preparing individual reports, monitoring 
the performance of the sanctions for perpetrators, participating in their re-socialization and providing support to both communities and victims. This strategic goal covers training for probation officers, judges, public attorneys, police officers, social workers and other categories of citizens who shall be involved in the entire probation process.

Partner institutions and organizations also play a specific and highly significant role and they have to be part of the established communication with a wider range of institutions and organizations in the process of re-socialization. Promoting positive reputation of probation services as well as the method of socially useful work ought to be another important segment, which is to start functioning once the probation system (service) has been established.

\section{CURRENT ISSUES AND DILEMMAS}

Professor Ljupčo Arnaudov, who has spent all his life working in the field of criminal law and performing sanctions, claims that practice has led him to the conclusion that punishments do not prevent crime. Statistical data in the last ten years show that almost every other convict is a recidivist (41-42\%). An additional problem in the Republic of Macedonia is the insufficient capacity of prisons. Namely, there are people who have received a court's decision for the given prison sentence and who are sometimes forced to wait for two years to serve their sentence. This means that while waiting for such a long period to serve thei sentence, the perpetrators are still free and pose a potential threat to the community.

So far, there have been 28 social workers from the Centers for social affairs throughout the entire Republic of Macedonia who have obtained work permit with alternative measures, and according to them, those measures are rarely used by judges giving sentences.

A feasibility study made in 2011 offered closer co-operation with prisons in the field of re-socialization and social adaptation of convicts in the period between 2010 and 2012. However, the effects of this whole process have not dealt with the problem entirely.

Dillemmas for and against probation may be more easily overcome if we mention some important advantages of the probation system. We will hereby point out the following:
- It is cheaper compared to prison sentences;

- Alleviating the work of penitentiary institutions by reducing prison population;

- Implementation of standards from international documents that insist on reducing imprisonment;

- Protection of convicted persons from the negative impact of the prison surrounding;

- Sanctions performed in the community enable the convicted persons to maintain close relationships with their families and community and represent an opportunity to maintain their employment status;

- Shortening the length of court procedure, thus increasing the efficiency of courts and reducing the costs of proceedings;

- Holistic approach to treating convicted persons offers protection to the community, reduces the number of victims and provides support.

\section{POSITIVE PRACTICE AND EXPERIENCE}

Doing the right thing with the right people, in the right way and at the right time is one of the maxims that can apply to practicing probation. The positive experience that serves as an example for the $\mathrm{RM}$ is the functioning of the probation service in Great Britain, where probation has been in use for over a century. Andrew Stallman and Sally Lester, as the leading experts in the field of probation in the UK, claim that around 250 thousand probation reports are made in Great Britain annually, and for $75 \%$ of them judges accept proposals of the probation body.

Practice in Great Britain shows that it is better to make the plan for alternative punishment in cooperation with and with the perpetrator's assent, at least in the initial stages, which is when the effects of the whole process are much greater. These are the three points that the British take into consideration:

1. evaluation of factors related to the crime committed;

2. the manner and motivation of the perpetrator to change his/her lifestyle and

3. the goals of monitoring as well as the plan for putting sanctions into practice.

The work of the probation service has effective goals that need to be reached, in particular: 
1. reducing recidivism;

2. reducing the number of convicts;

3. enabling perpetrators to integrate in the community;

4. enabling other members of the community to feel safe;

5. raising public trust in the penitentiary system.

In addition to the British positive experience, the Republic of Croatia has the same experience, though of much shorter length. Twelve probation offices have been set up in Croatia over the last year, with the aim to reduce the number of convicts in penitentiary institutions that house $20 \%$ more convicts than it has been planned (Zakon o probaciji, 2009).

According to financial estimates in the Republic of Croatia, one day in prison costs the country as much as three days of probation. It is believed that in this country in the foreseeable future, prison sentence will only be given to perpetrators of major crimes, who will be sentenced to longer imprisonment.

The establishment of probation offices in Croatia is seen as a way of humanizing execution of penitentiary sanctions, efficient re-socialization and re-integration of perpetrators in the social community as well as an organized way of providing support to victims, and families of both victims and perpetrators. It is worth mentioning that probation, as an alternative measure according to the Law on probation in Croatia, is determined exclusively under the written consent of the sentenced person, and the entire procedure is subject to written reports by relevant officers. Over the last three years, which is how long probation has been practiced in Croatia, persons included in the system have most frequently been working in public kitchens, decorating parks and forested areas, Red Cross activities and the like. People in charge of monitoring their behavior reported no problems.

\section{INTERNATIONAL SOURCES FOR ESTABLISHING PROBATION IN THE REPUBLIC OF MACEDONIA}

The central point to be regarded as the correct establishment of probation in our country are UN resolutions and recommendations of the Council of the European Union. Some of the most important acts that should not to be neglected include the following:
1. United Nations Standard Minimum Rules for Non-custodial Measures (these sanctions are used to determine minimum protection categories of people they are used for, with the aim to promote greater inclusion of the community in treating the perpetrator and developing community responsibility for the perpetrator).

2. Recommendation of the Council of Ministers R (99) 22 on overcrowded prisons and increase of prison population (it suggests potential measures for decreasing prison population in each phase of criminal proceedings).

3. Recommendation of the Council of Ministers R (92) 16 on the European rules on community sanctions and measures as the principal document in the sphere of probation and regulation of different contents as well as effective application of community sanctions and measures.

4. Recommendation REC (2000) 22 on improving the implementation of the European rules on community sanctions and measures.

All of the above suggested documents give us the opportunity to harmonize laws which are to be passed and there is a number of potential options and situations that have occurred in the countries where probation is implemented. Of course, one cannot disregard the fact that probation is one of the ways of establishing ethical standards within the international community.

\section{CONCLUSION}

The probation service in the Republic of Macedonia is a realtively new concept that is yet to be implemented. Moreover, the country is currently undergoing the process of drafting the National Strategy and Action Plan at the initiative of the Office for sanction enforcement.

Relying on the existing practice, the Criminal Law offered opportunities for two alternative punishments:

- Probation with protective monitoring; and

- Community work.

They have not been sufficiently practiced so far. According to statistical data in the Republic of Macedonia, there are 80 prisoners per one thousand citizens and it would be of great importance for the community to introduce probation and controlled freedom of perpetrators. 
EU countries implement probation in a different manner, as follows: In Holland, probation functions as a public service; in Scotland, it is organized by local self-governing units; in Italy, it is part of prison departments; while in our country, it is yet to be introduced as part of social centers, as is the case with Croatia.

Since there is still an ongoing debate regarding the need and the way in which probation service shall function, I sincerely hope this paper would make a contribution to resolving some of the dilemmas both among experts and scholars in the Republic of Macedonia.

\section{REFERENCE}

Cartledge, C.G., Tak, P.J.P., \& Tomić-Malić, M. (1981). Probation in Europe. Netherlands: European Assembly for Probation and After-care.

Jansen, M.F., \& Greve, V. (2003). The Danish Criminal Code \& the Danish Corrections Act. Copenhagen: DJøF Publishing.
Kimber, C. (1995). Criminal justice systems in Europe. Helsinki, Finland: European Institute for Crime Prevention and Control, affiliated with the United $\mathrm{Na}$ tions.

Kovčo Vukadin, I., Rajić, S., \& Balenović, M. (2009). Uspostava probacijskog sustava-novi izazov za Hrvatsku? Hrvatski ljetopis za kazneno pravo i praksu, 16(2), 711-751. (in Croatian)

Кривичен законик. (1996). Службен весник на Република Македонија, 37/96. Retrieved March 20, 2013, from http://www.slvesnik.com.mk/Issues/90E0B29D 702D49A48DBCC2239374B927.pdf (in Macedonian)

Ministry of Justice. (2006). The Swedish Judicial system: a brief presentation. Retrieved April 10, 2013, from http://polis.osce.org/countries/f/71/185/The\%20 Swedish\%20judicial\%20system.pdf

Šeparović, Z. (2003). Kazneno izvršno pravo i uvod u penologiju. Zagreb: Pravni Fakultet. (in Croatian)

Tot, B. (2007). Alternativa kazni zatvora: rad za opće dobro na slobodi. Policija i sigurnost, 16(1-2), 22-25. (in Croatian)

Zakon o probaciji. (2009). Narodne Novine, 153/09. Retrieved April 12, 2013, from http://www.zakon.hr/z/234/ Zakon-o-probaciji (in Croatian)

\section{SLUŽBA PROBACIJE KAO DEO KAZNENO-POPRAVNOG SISTEMA U REPUBLICI MAKEDONIJI}

\section{Rezime:}

U delu reforme kazneno-pravnog sistema Republike Makedonije predviđena je i reforma u sistemu za izvršavanje sankcija. Funkcionalan sistem za izvršavanje sankcija u savremenim kazneno-pravnim sistemima podrazumeva kompleksan pristup u kojem pored dimenzije kažnjavanja važnu ulogu imaju i dimenzije resocijalizacije i zaštite žrtve. U tom kontekstu ustanovljen je i tzv. sistem probacije.U Republici Makedoniji do sada nije postojao sistem probacije ali njegovi elementi su sadržani u postojećem zakonskom okviru u materijalnim i u procesnim odredbama. Pojedina rešenja prethodnog sustava mogu biti iskorišćena u funkciju uspostavljanja kontinuiteta institucionalnog i funkcionalnog nivoa. Polazna tačka uspostavljanja probacije počinje izmenama i dopunama Krivičnog zakona iz 2004. godine u kojim su u delu krivične sankcije uvedene alternativne mere: uslovna osuda, uslovna osuda sa zaštitnim nadzorom, uslovni prekid krivičnog postupka, društveno korisni rad, sudska opomena i kućni zatvor.

Ciljevi probacije pre svega su usmereni prema kreiranju i razvoju sistema redovne individualizovane procene počinilaca krivičnih dela, proceni rizika od ponavljanja krivičnog dela, identifikovanju objektivnih i subjektivnih razloga za prethodno kriminalno delovanje, kao i aktivnom i planski osmisljenom uključivanju u zajednicu osobama koji su već odslužile zatvorsku kaznu.
Ključne reči:

probacija,

sankcija,

alternativne mere,

krivično delo (prekršaj) 